\section{Krig på Rikshospitalets kvinneklinikk}

Sæter S

\section{Operatøren}

Knut Hauglands egen beretning. 268 s, ill. Oslo: Cappelen Damm, 2008. Pris NOK 349 ISBN 978-82-04-15284-8

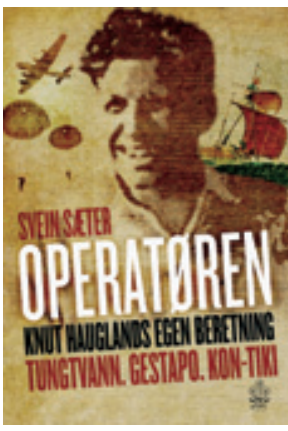

Hvorfor fascinerer den annen verdenskrig stadig? Hva er grunnen til at interessen topper seg igjen nå, mer enn 60 år etter? Historier om «krigen» vekker stor interesse av mange grunner: Ideologiske og politiske, fordi den tegnet så stor del av vår etterkrigstid, og personlige, fordi den kom til å prege mange menneskers liv.

En av de lavmælte har vært Knut Haug land (f. 1917). Tittelen på beretningen om hans innsats, Operatøren, skriker heller ikke. Han hadde passert de 90 da den ble skrevet. Haugland har ikke tidligere levert personlig bud verken på tungtvannsaksjonen, Kon-Tiki-ekspedisjonen, oppbyggingen av Norges Hjemmefrontmuseum eller Kon-Tiki-museet - men han spilte sentrale roller $i$ alt.

På loftet til den gamle kvinneklinikken i Stensberggaten sendte Haugland radiomeldinger til London vinteren 1944. Det var daværende reservelege ved klinikken, Finn Bøe (1906-70), som gjorde det mulig. Den gang bodde reservelegen på klinikken for å kunne være tilgjengelig ved behov. Gunnar Sønsteby (f. 1918), som selv hadde ligget i dekning der, knyttet kontakten mellom Bøe og Haugland. Tyskerne klarte å peile senderen, og de omringet klinikken 1. april 1944. Under dramatiske omstendigheter klarte Haugland å unnslippe. Dette er en spennende historie, der ekteparet Bøe tok store sjanser. Da jeg hørte Haugland fortelle denne historien på et seminar på Kvinneklinikken sommeren 2007, sa han at én forklaring på at han klarte komme seg ut av Gestapos jernring var at han, i motsetning til tyskerne, ikke var redd. Fremstillingen sannsynliggjøres av andre beretninger om opplevelser som har krevd en nesten usannsynlig kombinasjon av psykisk og fysisk styrke.

Kon-Tiki-ferden, der Haugland var telegrafist, er en av de best dokumenterte norske ekspedisjoner, også den med sin egen dramatikk. Personlig synes jeg derfor Hauglands beretning er mest fascinerende hva gjelder oppvekst, krigen og oppbyggingen av de to museene, Norsk Hjemmefrontmuseum og Kon-Tiki-museet. Av en interessant beretning kan man alltid ønske seg mer. Jeg ville gjerne ha hørt mer om hva som drev ham og om 1950- og 60-årene og de reaksjoner som må ha være uunngåelige etter så sterke opplevelser. Dessuten: Hva er det med Rjukan? Haugland og Sønsteby gikk i samme klasse. Claus Helberg (1919-2003) og Jens-Anton Poulsson (f. 1918) var også derfra.

Bildematerialet er rikt, mangfoldig og bevegende. Fotografiet av tungtvannssabotører på fjelltur i 1990 er en norsk klassiker: Eldre menn, med ryggsekk, som ikke er på sin første tur i fjellet.

Denne utgivelsen ville ikke blitt til uten innsatsen fra en kollega. Professor emeritus Jacob B. Natvig (f. 1934) er leder i Stiftelsen Nasjonalt medisinsk museum og inviterte Haugland til seminaret på Kvinneklinikken i juni 2007. Det var starten på et arbeid som har resultert i denne boken. Det har både han og Haugland all ære av.

\section{Per E. Børdahl}

Kvinneklinikken

Haukeland universitetssykehus

\section{Ingen Indian summer}

Behm J.

\section{Dr. Mumbai}

255 s. Oslo: Cappelen Damm, 2008.

Pris NOK 349

ISBN 978-82-02-27822-9

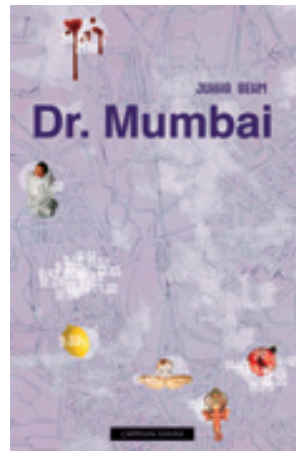

Dr. Mumbai er den finske vinneren av Den store nordiske romankonkurransen 2007, en konkurranse utlyst av de daværende nordiske Bonnierforlagene. Forfatteren Jukka Behm er 35 år, og dette er hans første bok. Utgangspunktet

er uvanlig: Den indiske barnepsykiateren Satish Rao er bosatt i Helsingfors, han snakker flytende finsk og lever i et samboerforhold med en finsk flyvertinne, Jonna, som han venter barn med. Jonna har to barn fra før. Den ene er autist. Barnas far har forsvunnet inn i en bisarr sekt, mens Jonnas gifte søster har et hemmelig forhold til Satish. Det dreier seg om heseblesende erotiske tekstmeldinger og kjappe formiddagsbesøk.

Hele handlingen i romanen finner sted i løpet av en dag i dr. Satish Raos liv. Dr. Raos mor og en tante har plutselig dukket opp og deres erklærte formål med besøket er å arrangere giftermål mellom Satish og en skikkelig indisk pike. Satish får innlosjert kvinnene i en kollegas leilighet (som han lar dem tro er hans egen) og unnlater å fortelle at han bor sammen med en høygravid finsk kvinne og hennes to små sønner.

Dr. Rao bærer med seg hele vår forestilling om Indias altomfattende varme og nærheten av utallige mennesker. Mumbais rastløse ambisjon kombinert med generasjoners tradisjon spiller også nøkkelroller i romanen. For dr. Rao har et forhold til livet som er omfangsrikt, mangfoldig og omtrentlig - som (vår forestilling om) India. Som barnepsykiater har han utviklet én overordnet teori og den har han lansert i en bok han har kalt «Gi meg nye foreldre». Budskapet er enkelt: Leger i den vestlige verden gir barn sterke psykofarmaka mens problemet er at de har ubrukelige foreldre som ikke er skikket til å ta seg av dem. En av ti foreldre duger ikke, erklærer dr. Rao. Den eneste fornuftige løsningen er at dårlige foreldre blir fratatt sine barn. Med et slikt budskap er den indiske legen - ikke uventet - blitt rikskjendis i Finland. Kollegene ser skjevt på ham, og foreldre som får besøk av barnevernet raser. Dr. Rao blir invitert til debattprogram og talkshow på TV. Og noen sender endog anonyme tekstmeldinger med trusler om snarlig død.

I løpet av et døgn utfolder livets farse, komedie og tragedie seg for dr. Rao i boken. Mumbais sol konfronteres med Finlands vintermørke.

Boken er skrevet av en sint ung mann. Han har noe å fortelle både leger og foreldre. Men til syvende og sist blir det ingen Indian summer for dr. Satish Rao i den strenge finske vinterkulden.

\section{May Brit Lund}

Lungemedisinsk avdeling

Rikshospitalet 